\title{
Influence of laser welding process parameters on weld pool geometry and duty cycle
}

\author{
Tadamalle, A.P. ${ }^{a}{ }^{,},{ }^{*}$ Reddy, Y.P. ${ }^{a}$, Ramjee, E. $^{b}$ \\ ${ }^{a}$ Department of Mechanical Engineering, Sinhgad College of Engineering, Vadgaon(Bk) Pune, India-411041 \\ ${ }^{b}$ Department of Mechanical Engineering, Jawaharlal Nehru Technological University, Kukkatpally, Hyderabad-85
}

\begin{abstract}
A B S T R A C T
In pulsed Nd:YAG laser welding process, the material melts and solidifies consecutively by a peak high power laser beam. The solidification time in this process is very less as compared to that of conventional welding process. The mode of welding process is governed by the process parameters like laser energy, pulse duration, pulse frequency, power and welding speed. This paper aimed at to examine the influence of welding speed and power on weld bead geometry and performance parameters such as duty cycle, pulse overlap, energy density and bead diameter. In this contest, first experiment is conducted on austenitic 304L stainless steel sheet by varying the welding speed from $2 \mathrm{~mm} / \mathrm{s}$ to $10 \mathrm{~mm} / \mathrm{s}$ and second experiment is conducted varying laser power from $300 \mathrm{~W}$ to $3500 \mathrm{~W}$. It was found from the experimental and analytical approach welding speed and laser power significantly affects on weld bead geometry, variation in bead diameter from pulse to pulse, duty cycle and effective pulse energy.
\end{abstract}

(C) 2013 PEI, University of Maribor. All rights reserved.

\author{
ARTICLE INFO \\ Keywords: \\ Duty cycle \\ Pulse overlap \\ Effective pulse energy \\ *Corresponding author: \\ Ashok_p_t@yahoo.com \\ (Tadamalle, A. P.)
}

\section{References}

[1] Balasubramanian, K. R., Buvanashekaran, G., Sankaranarayanasamy, K. (2010). Modeling of laser beam welding of stainless steel sheet butt joint using neural networks, CIRP Journal of Manufacturing Science and Technology, Vol. 3, No. 1, 80-84.

[2] Codigo Do Trabalho: 021018171. (2009). Characterization of Nd:YAG pulsed laser welded austenitic AISI 304L stainless steel, V congresso brasileiro de engenharia de fabricação 14 a 17 de abril de 2009, Belo Horizonte, Minas Gerais, Brasil. Online http://www.ipen.br/biblioteca/2009/eventos/14600.pdf.

[3] Balasubramanian, K. R., Siva Shanmugam, N., Buvanashekaran, G., Sankaranarayanasamy, K. (2008). Numerical and experimental investigation of laser beam welding of 304 stainless steel, Advances in Production Engineering and Management, Vol. 3, No. 2, 93-105.

[4] Singh, R., Alberts, M. J., A., Melkote, S. N. (2008). Characterization and prediction of the heat-affected zone in a laser-assisted mechanical micromachining process, International Journal of Machine Tools and Manufacturing, Vol. 48, No. 9, 994-1004.

[5] Hector, L. G., Chen, Y. L., Agarwal, S., Briant, C. L. (2004). Texture characterization of autogenous Nd:YAG laser welds in AA5182-O and AA6111-T4 aluminum alloys, Metallurgical and Materials Transactions, Vol. 35, No. 9, 3032-3038.

[6] Lee, M. F., Huang, J. C., Ho, N. J. (1996). Micro structural and mechanical characterization of laser-beam welding of a 8090 AL-Li thin sheet, Journal of material science, Vol. 31, 1455-1468.

[7] Masoumi, M., Marashi, S. P. H., Pouranvari, M. (2010). Metallurgical and Mechanical characterization of laser spot welded low carbon steel sheets, Steel research international, Vol. 81, No. 12, 1144-1151.

[8] Nath, A. K., Sridhar, R., Ganesh, P., Kaul, R. (2002). Laser power coupling efficiency in conduction and keyhole welding of austenitic stainless steel, Sadhana, Vol. 27, Part 3, 383-392. 
[9] Paleocrassas, A. G. (2009). Process characterization of low speed, fiber laser welding of AA 7075-T6 - application to fatigue crack repair, A dissertation submitted to the Graduate Faculty of North Carolina State University, in partial fulfilment of the requirements for the Degree of Doctor of Philosophy. Online: http://www.lib.ncsu.edu/resolver/1840.16/4796.

[10] Liao, Y. C., Yu, M. H. (2007). Effect of laser beam energy and incident angle on the pulse laser welding of stainless steel thin sheet, Journal of materials processing technology, Vol. 190, No. 1-3, 102-108.

[11] Zhang, Y. M. Kovacevic, R.; Li, L. (1996). Characterization and real time measurement of geometrical weld pool shape, Int. Journal of mech. Tools manufacturing, Vol. 36, No. 7, 799-816.

[12] Khan, M. M. A., Romoli, L., Fiaschi, M., Dini, G., Sarri, F. (2011). Experimental design approach to the process parameter optimization for laser welding of martensitic stainless steel in a constrained overlap configuration. Optics and Laser Technology, Vol. 43, No. 1,158-172.

[13] Arata, Y., Miyamoto, I. (1972). Theoretical analysis of weld penetration due to high energy density beam, Transaction of AWRI, Vol. 1, 11-16.

[14] Chang, W. S., Na, S. J. (2002). A study on prediction of the laser weld shape with varying heat source equations and the thermal distortion of a small structure in micro-joining, Journal of materials processing technology, Vol. 120, No. 1-3, 208-214. 